\author{
Resty Trisca Anggraini ${ }^{1}$ \\ Yeni Solfiah $^{2}$ \\ Hukmi $^{3}$
}

\section{ANALISIS KEMAMPUAN STATISTIK ANAK USIA 4-5 TAHUN DI PERUMAHAN PKS PT.BPLP KECAMATAN ENOK KABUPATEN INDRAGIRI HILIR}

\begin{abstract}
Abstrak
Penelitian ini bertujuan untuk mengetahui kemampuan statistik anak usia 4-5 tahun di Perumahan PKS PT.BPLP Kecamatan Enok Kabupaten Indragiri Hilir. Populasi pada penelitian ini adalah anak usia 4-5 tahun di Perumahan PKS PT.BPLP Kecamatan Enok Kabupaten Indragiri Hilir dan sampel pada penelitian ini berjumlah 7 orang anak yaitu 6 anak laki-laki dan 1 anak perempuan. Dalam pengumpulan data yang dilakukan oleh peneliti yaitu dengan menggunakan lembar observasi dan wawancara. Teknik analisis data penelitian ini menggunakan persentase. Penelitian ini adalah penelitian deskriptif dan berdasarkan analisis dalam pengelolaan data dan hasil persentase rekapitulasi dapat dilihat bahwa kemampuan statistik anak usia 4-5 tahun di Perumahan PKS PT.BPLP Kecamatan Enok Kabupaten Indragiri Hilir yaitu berjumlah 79 dengan rata-rata 70,54 \% dengan kategori berkembang sesuai harapan.
\end{abstract}

Kata Kunci: Kemampuan Statistik, Anak Usia 4-5 Tahun

\begin{abstract}
This study aims to determine the statistical ability of children aged 4-5 years in the PKS PT.BPLP Housing, Enok District, Indragiri Hilir Regency. The population in this study were children aged 4-5 years in PKS PT.BPLP Housing, Enok District, Indragiri Hilir Regency and the sample in this study was 7 children, namely 6 boys and 1 girl. In data collection carried out by researchers, namely by using observation and interview sheets. The data analysis technique of this study uses a percentage. This research is a descriptive study and is based on analysis in data management and the results of the percentage of recapitulation can be seen that the statistical abilities of children aged 4-5 years in the PKS Housing of PT.BPLP, Enok District, Indragiri Hilir Regency are 79 with an average of $70.54 \%$ by category develop as expected.
\end{abstract}

Keywords: Statistical Ability, Children 4-5 Years Old

\footnotetext{
${ }^{1}$ Pendidikan Guru PAUD, Fakultas Ilmu Pendidikan, Universitas Negeri Riau Alamat email hukmimukhtar75@gmail.com
} 


\section{PENDAHULUAN}

Pembelajaran di Taman Kanak-kanak di lakukan unuk mengembangkan dan menstimulasi enam aspek perkembangan anak yaitu nilai agama dan moral, nilai bahasa, nilai fisik motorik, nilai kognitif, nilai sosial emosional dan nilai seni. Semua aspek perkembangan tersebut di stimulasi dengan baik sesuai dengan tahap perkembangan anak. Banyak yang anak pelajari salah satunya yaitu matematika. Matematika merupakan mata pelajaran yang paling penting karena mata pelajaran matematika akan di temui anak di semua jenjang pendidikan dari pendidikan anak usia dini sampai pendidikan perguruan tinggi. Menurut Saracho anak usia dini terlahir sebagai matematikawan. Pernyataan ini tepat diberikan kepada anak usia dini karena megingat banyak konsep matematika yang berhubungan dengan kehidupan mereka sehari-hari salah satu nya yaitu konsep statistik.

Statistik dapat ditemukan dalam kehidupan sehari-hari. Dan untuk anak usia dini untuk fokus utamanya yaitu pada area di sekitar lingkungan anak untuk mengumpulkan data melalui pengalaman anak (Krogh \& Morehouse, 2020). Dan pada usia 4-5 tahun anak sudah mampu untuk mengklasifikasikan benda berdasarkan fungsi, bentuk atau warna atau ukuran nya, dan anak mampu untuk mengklasifikasikan benda ke dalam kelompok yang sama. Agar anak mampu mengklasifikasikan benda-benda tersebut maka anak harus melakukan percobaan untuk mengklasifikasikan benda-benda yang ada di dalam kelas atau di lingkungan sekitar anak (Peraturan Mendiknas Nomor : 137 Tahun 2014 Tentang Standar Nasional Pendidikan Anak Usia Dini)

Nadiem Makarim mengungkapkan bahwa di eradigital ilmu teknologi akan semakin berkembang dan hanya data yang berbicara. Sehingga kalau seseorang tidak bisa menganalisa data orang tidak akan bisa melihat cara, melihat tren secara kritikal dan seseorang akan terus di bohongi oleh data tersebut atau seseorang akan tertinggal. Jadi statistik adalah bahasa mengerti, mengakses data secara kritis, salah satu hal penting yang kurang diperhatikan di Indonesia (Priatna, 2019).

Matematika adalah ilmu yang tidak jauh dari realitas kehidupan manusia. Pada zaman purba, berabad-abad sebelum masehi, manusia telah mempunyai kesadaran ,akan bentuk bentuk benda di sekitarnya yang berada antara satu dengan yang lainnya. Batu berbeda dengan kayu, gunung berbeda dengan laut, pohon yang satu berbeda dengan pohon yang lainnya (Supatmono, 2009). Pengajaran matematika dapat dilakukan sejak usia dini sesuai dengan tahap perkemabangan dan pada usia dini pembelajaran matematika sebaiknya dilakukan dengan model bermain agar anak dapat mempelajari banyak hal tanpa merasa terbebani. Kemampuan mengklasifikasi pada anak usia dini merupakan salah satu kemampuan matematika yang melibatkan anak unuk mencari dan menemukan hal-hal yang sama dan mengelompokkannya berdasarkan jenis yang sama.

Secara umum konsep matematika anak usia dini ialah meliputi hal-hal berikut ini : memilih, membandingkan, dan mengurutkan, klasifikasi, menghitung, angka, pengukuran, geometri, membuabuat grafik, dan pemecahan masalah. Pada anak usia 4-5 tahun anak diharapkan mampu mengklasifikasikan benda berdasarkan bentuk atau warna atau ukuran atau mengelompokkan benda. Dan untuk mengetahui perkembangan kemampuan statistik anak dalam proses belajar mengajar anak harus bisa : 1. Mengklasifikasikan objek gambar 2 . Mengorganisasikan data, 3. Merepresentasikan data menggunakan objek gambar 4. Membandingkan data (Copley, 2000).

Menurut (Dodge, 1988) data, pengumpulan, pengorganisasian, dan representasi, di prasekolah melibatkan penyortiran, klasifikasi, grafik, penghitungan, pengukuran, dan perbandingan. instruksi di setiap bidang ini dapat dibangun di atas minat alami anak-anak dalam 
membuat koleksi. Sebagai bagian dari pengumpulan, anak-anak dapat mulai menyortir dan membuat set tanpa ada rencana dalam pikiran. lalu mereka menyortir dengan lebih sengaja misalnya, berdasarkan properti seperti warna, bentuk, atau ukuran. Ketika anak-anak mengembangkan dan memperbaiki keterampilan menyortir mereka, mereka dapat mengurutkan berdasarkan lebih dari satu atribut. Kemampuan ini diperkuat ketika guru mendorong anak untuk berbicara tentang aturan penyortiran mereka.

Melalui konsep statistik anak diharapkan mampu untuk melakukan seleksi, klasifikasi, menghitung, perbandingan (Smith, 2009). Pada umumnya kelas-kelas anak taman kanak-kanak menampilkan hasil karya, koleksi yang di pajang di dinding papan bulletin. Statistik adalah ilmu tentang data yang melibatkan pengumpulan, pemilahan, representasi, analisis, dan interpretasikan informasi. Untuk anak usia dini fokus utama adalah pengalaman informal dengan pengumpulan data, pengorganisasian dan tampilan data. Intruksi di setiap bidang ini dapat dibangun di atas minat alami anak-anak dalam membuat koleksi. Sebagai bagian dari pengumpulan, anak-anak dapat mulai menyotir tanpa ada rencana dalam pikiran. Lalu anak menyotir dengan sengaja misalnya, berdasarkan property seperti warna, bentuk, atau ukuran. Ketika anak-anak mengembangkan dan memperbaiki keterampilan menyortir mereka, mereka dapat mengurutkan beradasarkan lebih dari satu atribut. Kemampuan ini di perkuat ketika guru mendorong anak untuk berbicara tentang aturan penyortiran mereka.

Berdasarkan gejala di atas maka peneliti tertarik untuk melakukan penelitian berjudul " Analisi Kemampuan Statistik Anak Usia 4-5 Tahun Di Perumahan Pks Pt. Bplp Kecamatan Enok Kabupaten Indragiri Hilir “.

\section{METODE}

Penelitian ini menggunakan metode penelitian deskriptif yang bertujuan untuk mengetahui kemampuan statistik anak usia 4-5 tahun di perumahan PKS PT. BPLP Kecamatan Enok Kabupaten Indragiri Hilir. Penelitian ini hanya melibatkan satu variabel yaitu kemampuan statistik anak usia 4-5 tahun. Populasi dari penelitian ini adalah seluruh anak usia 4-5 tahun di perumahan PKS PT. BPLP Kecamatan Enok Kabupaten Indragiri Hilir. Sampel penelitian ini menggunakan Teknik sampel jenuh sebanyak 7 anak. Sedangkan Data yang digunakan adalah data primer yang diambil langsung oleh responden dengan pengumpulan data melalui lembar observasi, dokumentasi dan wawancara.

Teknik analisis data pda penelitian ini menggunakan rumus persentase yang dikemukakan oleh (Purwanto, 2006)

\section{Keterangan:}

$$
\mathrm{NP}=\frac{\mathbf{R}}{\mathbf{S M}} x 100 \%
$$

$\mathrm{NP}=$ nilai persen yang dicari atau diharapkan

$\mathrm{R}=$ skor mentah yang diperoleh siswa

$\mathrm{SM}=$ skor maksimum ideal dari tes yang bersangkutan

$100=$ bilangan tetap

\section{HASIL DAN PEMBAHASAN}

Penelitian ini dilakukan di Perumahan PKS PT.BPLP Kecamatan Enok Kabupaten Indragiri Hilir berdiri pada tahun 2002. Perumahan PKS PT.BPLP terletak di Desa Bagan Jaya RT 028 RW 010, Kecamatan Enok Kabupaten Indragiri Hilir dan manager dan ktu perumahan saat ini adalah bapak Perry sukamto dan bapak faisol. Sebelum melakukan penelitian di perumahan PKS Pt.BPLP Kecamatan Enok Kabupaten Indragiri Hilir peneliti terlebih dahulu 
mempersiapkan lembaran observasi dan memohom izin ke pada manager PT.BPLP. Setelah mendapatkan izin dari Manager PT.BPLP Kecamatan Enok Kabupaten Indragiri Hilir peneliti melakukan pengambilan data yang dilakukan dengan observasi anak dan pengisian lembar observasi. Pengisian lembar observasi di lakukan pada tanggal 29 september 2020 - 10 oktober 2020. Adapun hasil dari penelitian ini dapat dilihat dibawah ini

\section{a. Hasil Penelitian}

Hasil pengelolaan data kemampuan statistik anak usia 4-5 tahun di perumahan Perumahan PKS PT.BPLP Kecamatan Enok Kabupaten Indragiri Hilir secara umum dapat di lihat dalam table berikut ini :

Tabel 4.1 Rekapitulasi indikator kemampuan statistik anak usia 4-5 tahun di Perumahan PKS PT.BPLP Kecamatan Enok Kabupaten Indragiri Hilir.

\begin{tabular}{llllll}
\hline No & Indikator Penelitian & $\begin{array}{l}\text { Skor } \\
\text { Ideal }\end{array}$ & $\begin{array}{l}\text { Skor } \\
\text { Faktual }\end{array}$ & $\%$ & Keterangan \\
\hline 1 & $\begin{array}{l}\text { Anak mengklasifikasikan } \\
\text { objek gambar }\end{array}$ & $\mathbf{2 8}$ & $\mathbf{2 1}$ & $\mathbf{7 5}$ & BSH \\
\hline 2 & $\begin{array}{l}\text { Anak Mengorganisasikan } \\
\text { data }\end{array}$ & $\mathbf{2 8}$ & $\mathbf{1 8}$ & $\mathbf{6 4 , 2 9}$ & BSH \\
\hline $\begin{array}{l}\text { Anak merepresentasikan } \\
\text { data menggunakan objek } \\
\text { gambar }\end{array}$ & $\mathbf{2 8}$ & $\mathbf{2 0}$ & $\mathbf{7 1 , 4 3}$ & BSH \\
\hline $\begin{array}{l}\text { Anak membandingkan } \\
\text { data }\end{array}$ & $\mathbf{2 8}$ & $\mathbf{2 0}$ & $\mathbf{7 1 , 4 3}$ & BSH \\
$\begin{array}{l}\text { Jumlah } \\
\text { Rata-rata }\end{array}$ & $\mathbf{1 1 2}$ & $\mathbf{7 9}$ & $\mathbf{2 8 2 , 1 5}$ & \\
\hline
\end{tabular}

Sumber: Data Olahan Hasil Penelitin, 2020 lampiran halaman

Berdasarkan rekapitulasi indikator kemampuan statistik anak usia 4-5 tahun di Perumahan PKS PT.BPLP Kecamatan Enok Kabupaten Indragiri Hilir diketahui bahwa secara keseluruhan indikator kemampuan statistik anak yang telah diamati berada pada kategori berkembang sesuai harapan dengan jumlah persentase $70,54 \%$. Untuk lebih jelas melihat perkembangan kemampuan statistik anak usia 4-5 tahun di Perumahan PT.BPLP Kecamatan Enok Kabupaten Indragiri Hilir dengan memperhatikan grafik berikut ini :

Gambar 4.1 Rekapilitus indikator kemampuan statistik anak usia 4-5 tahun di Perumahan PKS PT.BPLP Kecamatan Enok Kabupaten Indragiri Hilir.

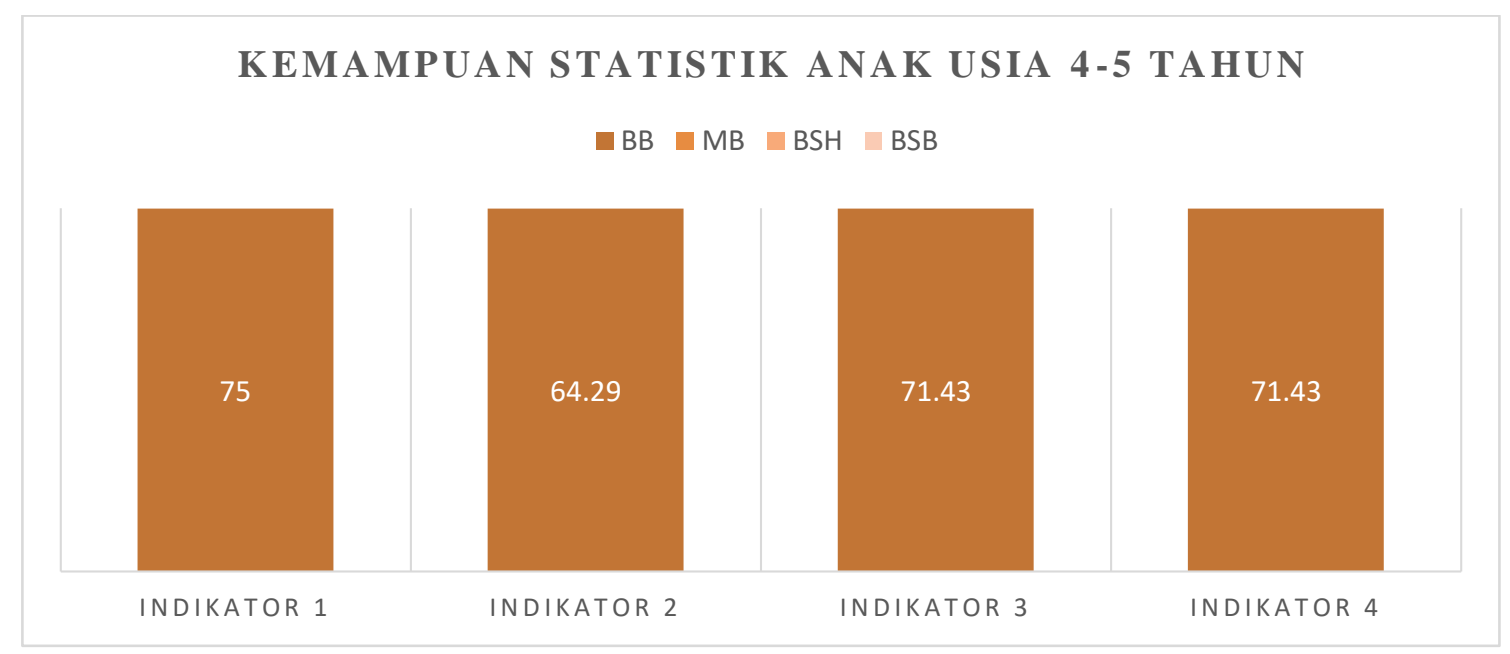


Dari gambar tersebut dapat di jelaskan bahwa kemampuan statistik pada anak usia 4-5 tahun di Perumahan PKS PT.BPLP Kecamatan Enok kabupaten Indragiri Hilir terdiri dari 4 indikator. Persentase yang tertinggi ialah pada indikator yang pertama yaitu anak anak mengurutkan dan mengklasifikasikan objek sesuai dengan atributnya $75 \%$ termasuk kategori "berkembang sesuai harapan" sedangkan persentase terendah pada indikator yang ke dua yaitu anak mengorganisasikan data $64,29 \%$ termasuk kategori "berkembang sesuai harapan".

Berikut ini tabel perkembangan kemampuan statistik anak usia 4-5 tahun di Perumahan PKS PT.BPLP Kecamatan Enok Kabupaten Indragiri Hilir.

Tabel 4.2 Frekuensi distribusi indikator anak mengurutkan dan mengklasifikasikan objek sesuai dengan atributnya.

\begin{tabular}{lllll}
\hline No & Kategori & Skor & F & $\%$ \\
\hline 1. & Belum Berkembang & 1 & 0 & 0 \\
2. & Mulai Berkembang & 2 & 1 & 14,29 \\
3. & Berkembang Sesuai Harapan & 3 & 5 & 71,43 \\
4. & Berkembang Sangat Baik & 4 & 1 & 14,29 \\
\hline
\end{tabular}

Sumber: Data Olahan Hasil Penelitian, 2020

Dari tabel 4.2 di atas dapat di jelaskan bahwa pada indikator pertama, anak yang mendapatkan skor 2 yaitu ada 1 orang anak dengan nilai persentase 14,29\%, anak yang mendapatkan skor 3 yaitu ada 5 orang anak dengan nilai persentase 71,43\%, dan anak yang mendapatkan skor 4 yaitu ada 1 orang anak dengan nilai persentase $14,29 \%$.

Untuk melihat lebih jelas frekuensi distribusi indikator anak mengurutkan dan mengklasifikasikan objek sesuai dengan atributnya.

\section{Gambar 4.2 frekuensi distribusi indikator anak mengurutkan dan mengklasifikasikan objek sesuai dengan atributnya.}

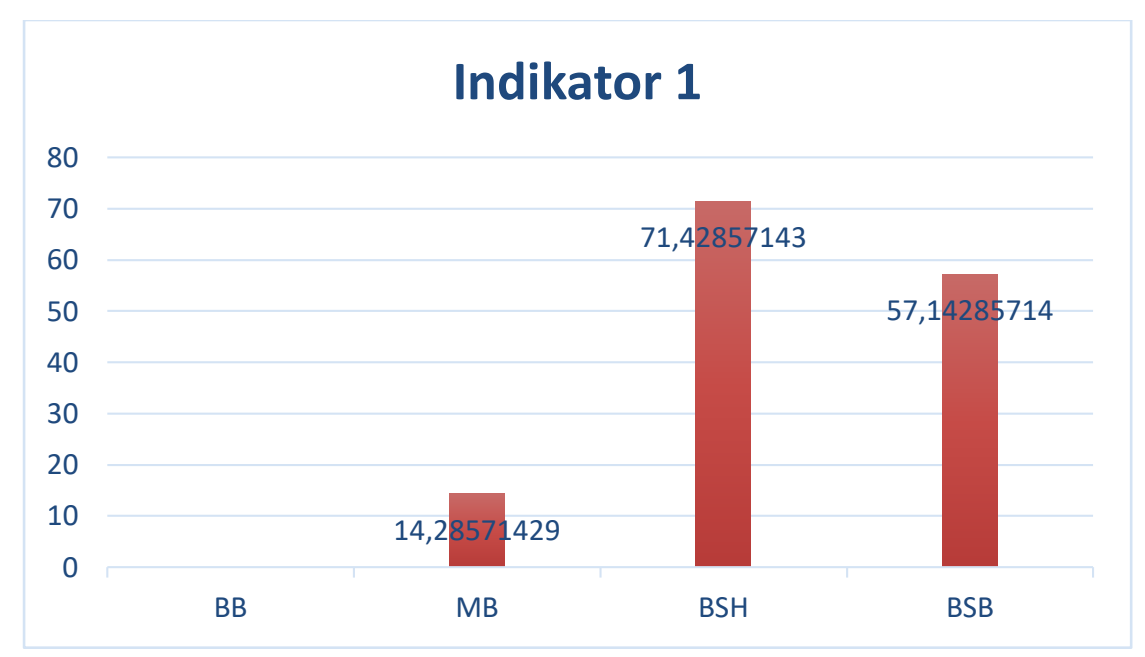

Dari analisis tersebut dapat dijelaskan bahwa analisis kemampuan statistik anak usia 4-5 tahun di Perumahan PKS PT.BPLP Kecamatan Enok Kabupaten Indragiri Hilir pada indikator 1 , nilai tertinggi sebanyak 5 orang anak yang berkembang sesuai harapan. 
Tabel 4.3 frekuensi distribusi indikator anak mengorganisasikan data

\begin{tabular}{lllll}
\hline No & Kategori & Skor & F & $\%$ \\
\hline 1. & Belum Berkembang & 1 & 0 & 0 \\
2. & Mulai Berkembang & 2 & 3 & 42,86 \\
3. & Berkembang Sesuai Harapan & 3 & 4 & 57,14 \\
4. & Berkembang Sangat Baik & 4 & 0 & 0 \\
\hline
\end{tabular}

Sumber: Data Olahan Hasil Penelitian, 2020

Dari tabel 4.3 di atas dapat di jelaskan bahwa pada indikator kedua, anak yang mendapatkan skor 2 yaitu ada 3 orang anak dengan nilai persentase $42,86 \%$, dan anak yang mendapatkan skor 3 yaitu ada 4 orang anak dengan nilai persentase 57,14\%,

Untuk melihat lebih jelas frekuensi distribusi indikator anak mengorganisasikan data.

\section{Gambar 4.3 frekuensi distribusi indikator anak mengorganisasikan data}

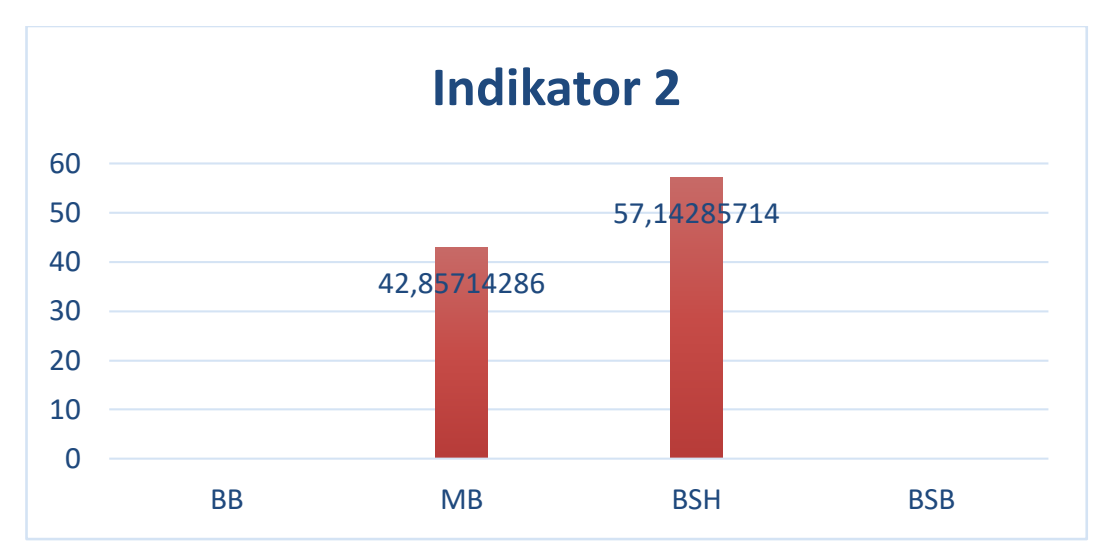

Dari analisis tersebut dapat dijelaskan bahwa analisis kemampuan statistik anak usia 4-5 tahun di Perumahan PKS PT.BPLP Kecamatan Enok Kabupaten Indragiri Hilir pada indikator 2 , nilai tertinggi sebanyak 4 orang anak yang berkembang sesuai harapan.

Tabel 4.4 frekuensi distribusi indikator anak merepresentasikan data menggunakan gambar dan grafik

\begin{tabular}{lllll}
\hline No & Kategori & Skor & F & $\%$ \\
\hline 1. & Belum Berkembang & 1 & 0 & 0 \\
2. & Mulai Berkembang & 2 & 2 & 28,58 \\
3. & Berkembang Sesuai Harapan & 3 & 4 & 57,14 \\
4. & Berkembang Sangat Baik & 4 & 1 & 14,29 \\
\hline
\end{tabular}

Sumber: Data Olahan Hasil Penelitian, 2020

Dari tabel 4.4 di atas dapat di jelaskan bahwa pada indikator ketiga, anak yang mendapatkan skor 2 yaitu ada 2 orang anak dengan nilai persentase 28,58\%, anak yang mendapatkan skor 3 yaitu ada 4 orang anak dengan nilai persentase $57,14 \%$, dan anak yang mendapatkan skor 4 yaitu ada 1 orang anak dengan persentase 14,29\%.

Untuk melihat lebih jelas frekuensi distribusi indikator anak merepresentasikan data menggunakan gambar dan grafik.

Gambar 4.4 frekuensi distribusi indikator anak merepresentasikan data menggunakan gambar dan grafik 


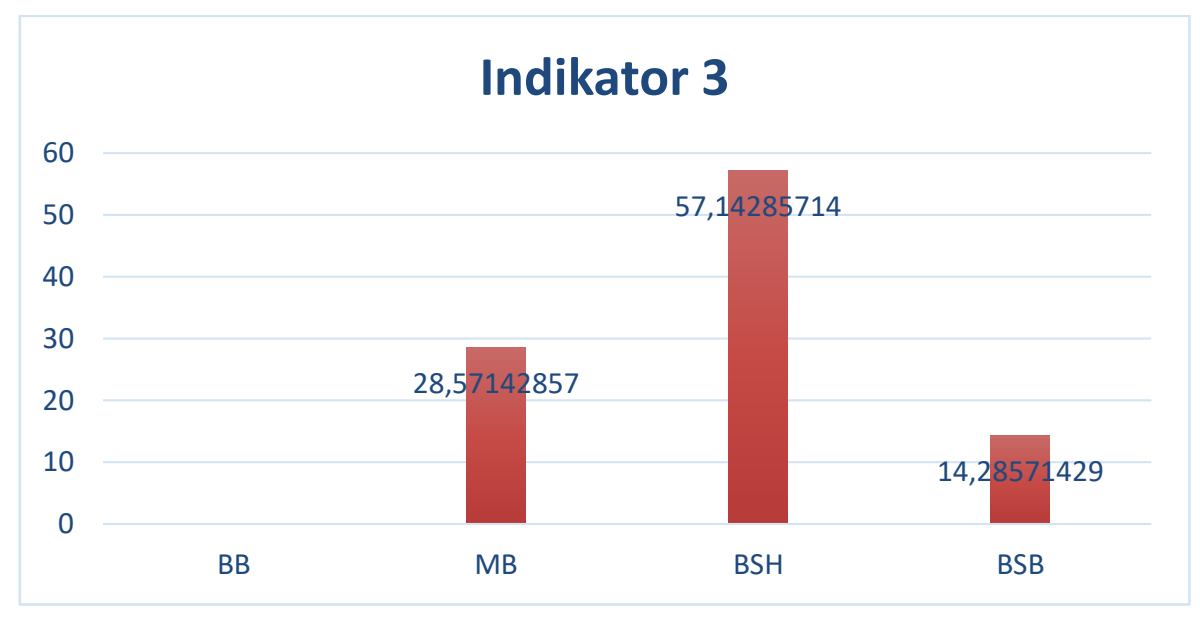

Dari analisis tersebut dapat dijelaskan bahwa analisis kemampuan statistik anak usia 4-5 tahun di Perumahan PKS PT.BPLP Kecamatan Enok Kabupaten Indragiri Hilir pada indikator 3 , nilai tertinggi sebanyak 4 orang anak yang berkembang sesuai harapan.

Tabel 4.5 frekuensi distribusi indikator anak membandingkan data

\begin{tabular}{lllll}
\hline No & Kategori & Skor & F & $\%$ \\
\hline 1. & Belum Berkembang & 1 & 0 & 0 \\
2. & Mulai Berkembang & 2 & 2 & 28,58 \\
3. & Berkembang Sesuai Harapan & 3 & 4 & 57,14 \\
4. & Berkembang Sangat Baik & 4 & 1 & 14,29 \\
\hline
\end{tabular}

Sumber: Data Olahan Hasil Penelitian, 2020

Dari tabel 4.5 di atas dapat di jelaskan bahwa pada indikator ketiga, anak yang mendapatkan skor 2 yaitu ada 2 orang anak dengan nilai persentase $28,58 \%$, anak yang mendapatkan skor 3 yaitu ada 4 orang anak dengan nilai persentase $57,14 \%$, dan anak yang mendapatkan skor 4 yaitu ada 1 orang anak dengan persentase 14,29\%.

Untuk melihat lebih jelas frekuensi distribusi indikator anak membandingkan data

Gambar 4.5 frekuensi distribusi indikator anak membandingkan data

\section{Indikator 4}

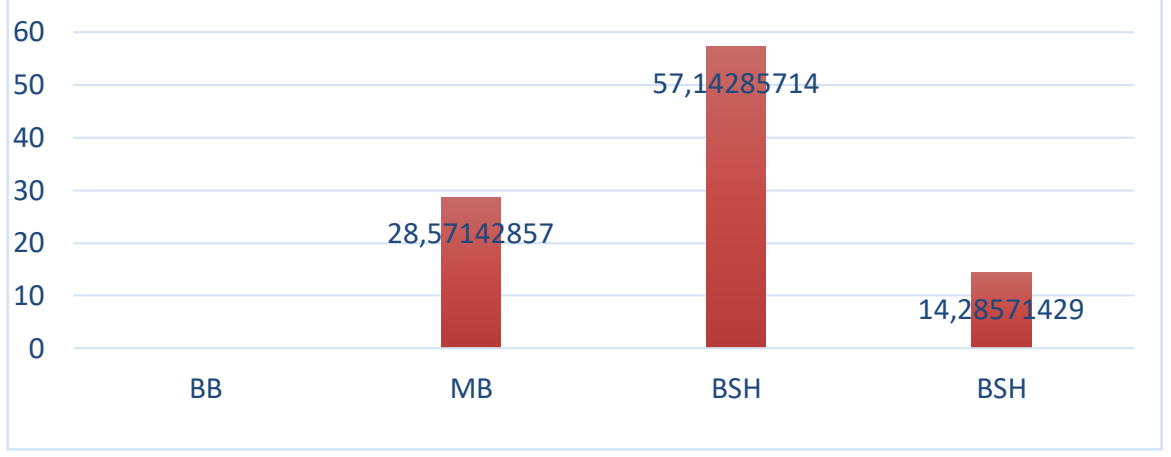

Dari analisis tersebut dapat dijelaskan bahwa analisis kemampuan statistik anak usia 4-5 tahun di Perumahan PKS PT.BPLP Kecamatan Enok Kabupaten Indragiri Hilir pada indikator 3 , nilai tertinggi sebanyak 4 orang anak yang berkembang sesuai harapan.

\section{b. Pembahasan Hasil Penelitian}

Pembahasan hasil penelitian yang dilakukan dengan hasil yang di peroleh dengan melakukan observasi dan di perkuat dengan hasil wawancara yang diajukan kepada masing- 
masing orang tua anak di Perumahan PKS PT.BPLP Kecamatan Enok Kabupaten Indragiri Hilir. Berdasarkan analisis pengola data dan hasil persentase di atas dapat dilihat bahwa kemampuan statistk anak usia 4-5 tahun di Perumahan PKS PT.BPLP Kecamatan Enok Kabupaten Indragiri Hilir diperoleh dengan jumlah nilai 79 dengan nilai rata-rata 70,53\%.

Skor akhir tertinggi yaitu pada indikator "anak mampu mengklasifikasikan objek gambar" degan jumlah skor 21. Indikator ini mendapatkan nilai skor tertinggi sesuai dengan penelitian pendapat Ginsburg dalam Yulaifah (2013:3) supaya anak usia dini mampu menggolongkan (mengklasifikasikan) atau menyortir benda-benda harus memahami konsep"saling emiliki kesamaan atau keserupaan" dan "perbedaan". Ketika anak sudah mampu memahami konsep tersebut maka akan mudah dalam dalam melakukan klasifikasi terhadap benda-benda. Klasifikasi juga tidak hanya didasarkan pada pengelompokan warna, bentuk, dan ukuran saja, akan tetapi juga dapat didasarkan pada ciri-ciri yang sama,, jenis yang sama, ataupun kombinasi dari kategori-kategori tersebut. Misalnya klasifikasi berdasarkan warna dan ukuran atau berdasarkan warna, ukuran, dan bentuk.oleh karenanya kognitif yang lebih tinggi, sehingga hal ini penting untuk dikembangkan pada anak.

Dan didukung oleh hasil wawancara bersama orang tua anak mengenai "bagaimana kemampuan statistik anak saat di rumah?" dan diperoleh jawaban "saat berada di rumah anak sudah bisa mengelompokkan benda sesuai kelompokknya misalnya, saat mamanya selesai menyuci piring dan anak yang menyusun piring ke rak piring anak sudah bisa meletakkan piring ke tempat piring, sendok ke tempat sendok, gelas ke tempat gelas, garpu ketempat garpu.

Pembelajaran yang dilakukan oleh ibu kepada anak selama di rumah yaitu dengan menggunakan konsep bermain sambil belajar, ibu menciptakan suasana belajar yang tidak membosankan untuk anak. Dalam pembelajaran statistik ibu menggunakan tutup botol berbeda beda warna dan ibu meminta anak untuk mengklasifikasikan tutup botol tersebut berdasarkan warna yang sama. Dengan menciptakan suasana asik maka dapat meningkatkan minat belajar anak dengan baik. Oleh sebab itu kemampuan anak dalam mengklasifikasikan benda berkembang sesuai harapan.

Peran orang tua sangat penting untuk anak dalam pembelajaran di rumah terutama seorang ibu, karena orang tua adalah pendidik yang selalu berusaha sebaik mungkin untuk kemajuan anaknya. Menurut Ki Hadjar Dewantara mengatakan "Pokoknya pendidikan harus terletak di dalam pangkuan ibu dan bapa, karena hanya da orang inilah yang dapat berhamba pada sang anak dengan semurni-murninya dan seikhlas-ikhlasnya, sebab cinta dan ksihnya kepada anak-anaknya boleh dibilang cinta kasih tak terbatas.

Apa lagi di masa adanya wabah atau virus yang sedang menyerang manusia di seluruh dunia saat ni yang dikenal dengan covid 19 yang dapat menyerang siapapun sehingga kita juga harus waspada pada keadaan ini. Pada saat ini peran oaring tua sangat di perlukan sebagai pengganti guru untuk membantu dan membimbing anak proses pembelajaran selama di rumah. Orang tua juga harus memberikan dukungan kepada anak agar anak semangat untuk belajar dan tetap melaksanakan belajar walaupun dirumah agar anak memperolah prestasi yang baik.

Dalam penelitian yang dilakukan oleh (Cahyati \& Kusumah, 2020) yang berjudul "Peran Orang Tua Dalam Menerapkan Pembelajaran Di Rumah Saat Pandemi Covid 19" dan hasil penelitian tersebut dapat di simpulkan bahwa orang tua merasa pembelajaran di rumah sangat efektif dibandingkan dengan kegiatan pembelajaran di rumah, hal ini karena pembelajaran di rumah lebih cendrerung kepada banyaknya pemberian tugas yang dapat dibantu dan dibimbing pengerjaannya oleh orang tua di rumah. Dan banyak orang tua yang setuju jika selama pembelajaran dirumah, orang tua lah yang membantu mengerjakan tugas yang diberikan oleh guru.

Selanjutnya didukung juga oleh penelitian yang dilakukan oleh (Ulandari et al., 2018), yang berjudul "Meningkatkan Kemampuan Mengklasifikasi Melalui Bermain Kostruksi Sifat Padat" hasil dari penelitian tersebut dapat di simpulkan bahwa penelitian ini bertujuan untuk membantu menstimulasi kemampuan mengklasifikasi melalui bermain konstruksi dengan media yang bersifat padat yaitu kertas dan balok. Berdasarkan hasil penelitian dapat disimpulkan dalam hasil pengamatan yang dilakukan bahwa dengan aspek warna anak sudah dapat 
mengelompokkan 7 buah balok berdasarkan warna, dibandingkan dengan aspek lainnya dapat meningkatkan kemampuan mengklasifikasi anak dengan nilai baik.

Skor akhir terendah terdapat pada indikator "anak mengorganisasikan data" dengan jumlah skor 18. Disebabkan oleh anak yang sulit di ajarkan oleh orang tua selama di rumah sehingga membuat anak kurang memahami dalam mengorganisasikan data.

Dalam indikator anak mengorganisasikan data masih ada anak yang belum mengenal dan mengurutkan angka dari 1-10 dan kemampuan berhitung anak belum berkembang secara optimal. Menurut permendikbud 137 anak usia 4-5 tahun mampu membilang banyak benda satu sampai sepuluh, anak mengenal konsep bilangan, mengenal lambang bilangan, sedangkan yang peneliti temui di Perumahan PKS PT.BPLP Kecamatan Enok Kabupaten Indragiri Hilir anak masih belum bisa mengenal lambang bilangan secara optimal.

Sejalan dengan penelitian yang dilakukan oleh (Apriyansyah, 2018) yang berjudul "Peningkatan Kemampuan Berhitung Permulaan Anak Usia 4-5 tahun Melalui Media Permainan Stick Angka " hasil dari penelitian tersebut dapat di simpulkan bahwa pada anak usia 4-5 tahun kemampuan berhitungnya belum berkembang secara optimal, seperti terlihat masih ada pendidik yng belum dapat mengurutkan angka dari satu sampai sepuluh, belum dapat membedakan jumlah banyak sedikit.

Selanjutnya yaitu hasil dari wawancara dan observasi yang telah dilakukan oleh peneliti, dapat di simpulkan bahwa perkembangan kemampuan statistik usia 4-5 tahun di Perumahan PKS PT.BPLP Kecamatan Enok Kabupaten Indragiri Hilir anak telah berkembang secara optimal karna anak sudah mampu mengklasifikasikan benda secara natural di kehidupan seharihari.

\section{SIMPULAN}

Berdasarkan hasil pengolahan data, dapat di simpulkan bahwa : Analisis kemampuan statistik anak usia 4-5 tahun di perumahan PKS PT. BPLP Kecamatan Enok Kabupaten Indragiri Hilir memperolah hasil rata-rata 70,54 \% dengan kategori berkembang sesuai harapan. Ini menunjukkan bahwa kemampuan statistik anak usia 4-5 tahun di perumahan PKS PT. BPLP sudah optimal dalam perkembangannya.

\section{DAFTAR PUSTAKA}

Apriyansyah, C. (2018). PENINGKATKAN KEMAMPUAN BERHITUNG PERMULAAN ANAK USIA 4-5 TAHUN MELALUI MEDIA PERMAINAN. Tumbuh Kembang: Kajian Teori Dan Pembelajaran PAUD, 5(1), 46-63.

Cahyati, N., \& Kusumah, R. (2020). Peran Orang Tua Dalam Menerapkan Pembelajaran Di Rumah Saat Pandemi Covid 19. Jurnal Golden Age, 4(01), 152-159.

Copley, J. V. (2000). The young child and mathematics. ERIC.

Dodge, D. T. (1988). The Creative Curriculum for Early Childhood. ERIC.

Krogh, S. L., \& Morehouse, P. (2020). The early childhood curriculum: Inquiry learning through integration. Routledge.

Priatna, T. (2019). Disrupsi Pengembangan Sumber Daya Manusia Dunia Pendidikan di Era Revolusi Industri 4.0. Pusat Penelitian dan Penerbitan UIN Sunan Gunung Djati.

Purwanto, N. (2006). Prinsip dan Teknik Evaluasi Pengajaran. Bandung: Remaja Rosda Karya. Smith, S. S. (2009). Early Childhood Mathematics.

Supatmono, C. (2009). Matematika asyik. Jakarta: Grasindo.

Ulandari, V., Saparahayuningsih, S., \& Yulidesni, Y. (2018). Meningkatkan Kemampuan Mengklasifikasi melalui Bermain Konstruktif Sifat Padat. Jurnal Ilmiah Potensia, 3(2), 127-132. 